Article

\title{
Towards a Food-Based Intervention to Increase Protein Intakes in Older Adults: Challenges to and Facilitators of Egg Consumption
}

\author{
Emmy van den Heuvel ${ }^{1}{ }^{(D}$, Jane L. Murphy ${ }^{2}$ and Katherine M. Appleton ${ }^{1, *} \mathbb{C}$ \\ 1 Research Centre for Behaviour Change, Department of Psychology, Faculty of Science and Technology, \\ Bournemouth University, Poole BH12 5BB, UK; mvandenheuvel@bournemouth.ac.uk \\ 2 Faculty of Health and Social Sciences, Bournemouth University, Bournemouth BH1 3LT, UK; \\ jmurphy@bournemouth.ac.uk \\ * Correspondence: k.appleton@bournemouth.ac.uk; Tel.: +44-(0)-1202-965985; Fax: +44-(0)-1202-965314
}

Received: 21 August 2018; Accepted: 26 September 2018; Published: 2 October 2018

\begin{abstract}
Background: Dietary protein intake is important for health. Eggs, as a protein-rich food with characteristics that appeal to older adults, may provide opportunities for increasing protein intake. Interventions that focus on the challenges or facilitators that affect a large proportion of the population will be of increased impact on a population-wide scale. This work aimed to investigate the relative importance of a number of challenges to and facilitators of egg consumption in a UK population-wide sample of older adults. Methods: A cross-sectional postal questionnaire, measuring habitual egg intake, reasons for eating/not eating eggs and a range of demographic and lifestyle characteristics, was administered by post to 1082 older adults. Results: 230 questionnaires suitable for analysis were returned (110 females, ages 55-80+ years). Habitual egg intake ranged from 1-89 eggs/month, mean (standard deviation) = 18 (13) eggs/month. Reasons for eating/not eating eggs were reduced using Principal Components Analysis to 23 challenges and facilitators of egg consumption. Regression analyses revealed habitual egg intake to be associated with 10 challenges and facilitators (smallest $\beta=0.14, p=0.04$ ), and with protein consumption, age and Body Mass Index (smallest $\beta=0.14, p=0.03$ ). Discussion: Many possibilities for future intervention based on existing challenges or facilitators were found. Our results suggest that strategies to increase egg consumption in older adults should focus on: improving liking, tastiness and adding variety; promoting eggs as an everyday type of food; reducing stereotypes about who does and who does not consume eggs; and promoting eggs for people who have noticed the effects of ageing on their food intake. Strategies that highlight value-for-money may be counterproductive. Future work evaluating the value of these strategies for improving protein intake in this age group would be of value.
\end{abstract}

Keywords: egg consumption; dietary protein consumption; older adults; questionnaires

\section{Introduction}

The older population is rapidly increasing [1], thus, maintaining or improving health in later years is becoming increasingly important. Dietary protein intake has a considerable impact on health and physical functioning [2-4]. Protein intake has been associated with functional abilities [5], reduced risk of incident frailty [6,7], falls and fractures [8,9], decreased bone mineral density and bone mass [10-13], improved glucose control in type 2 diabetes [14], lower blood pressure and lower risk of coronary heart disease [15-17]. Moreover, increasing protein intake has been positively related to the prevention of [18], and recovery $[19,20]$ from injury, and may positively influence muscle mass and function in the elderly $[6,21-26]$. 
Energy intake in adults decreases approximately $25 \%$ between the ages of 40 to 70 years old [27], and older adults are known to eat less protein than younger adults [28-30]. Protein-specific under-nutrition in older adults ranges from $1 \%-24 \%$ if based on the estimated average requirement, but it can be as high as 77\% when higher intake recommendations are used [30-33].

Previous studies have shown that older adults face specific challenges in consuming and increasing dietary protein. Barriers to eating protein-rich foods include sensory characteristics, the physical abilities involved in food preparation and food shopping, and eating capabilities, e.g., in biting, chewing, or swallowing, [4,27,28,34,35]. It has also been shown that perceived convenience, value for money, and low perishability are important positive predictors of intakes of protein-rich foods in older adults [35], and that intakes of these foods in this population are strongly affected by familiarity with the foods, habits and past eating behaviour $[34,36]$. These latter findings highlight the potential relevance of a food-based approach for increasing protein intake.

Eggs are a nutrient dense, high quality source of protein [37,38]. Sensory analyses with older adults have demonstrated that eggs are popular for their soft texture, while meats are characterized to have more difficult textures [39]. Compared to other protein-rich foods, eggs are also easy to cook, have a long shelf-life and also have a low cost [40,41]. Moreover, eggs are a familiar food to many people [38]. Given these characteristics, eggs may help increase dietary protein intakes in older adults.

However, to date, little research has investigated egg consumption in older adults, or identified the specific challenges to consuming eggs for this population. To encourage consumption, details of the challenges are required. Interventions that either address challenges or maximise facilitators will have increased chances of success compared to interventions that are less developed [42,43]. Furthermore, interventions that focus on challenges or facilitators that have an impact on a large proportion of the population will be of increased impact on a population-wide scale [42]. Previous qualitative work by ourselves identified all the reasons given for eating and not eating eggs in a sample of 42 British older adults [44]. Sixty-nine different reasons for eating and not eating eggs were found, many related to both consumption and non-consumption in different individuals. The current study aimed to extend this work, to investigate the relative importance of each of these reasons for egg consumption in UK older adults on a population-wide basis.

\section{Methods}

The study was undertaken using a cross-sectional postal questionnaire administered to a national sample of adults from the UK over 55 years old. Agreement/disagreement with each of the previously identified reasons for egg consumption/non-consumption was assessed alongside habitual egg intake and various demographic and lifestyle characteristics. Relative importance of each reason was then attained using regression analyses. Ethical approval for this study was granted by the Research Ethics Committee of Bournemouth University prior to commencement (ID: 8171).

\subsection{Questionnaire}

The questionnaire contained a food frequency questionnaire (FFQ) to measure habitual egg intake, an FFQ to measure habitual intakes of other protein-containing foods, a series of statements on reasons for eating/not eating eggs and a range of demographic and lifestyle characteristics, in this order.

Egg Intake: The FFQ for eggs listed 18 different types of egg preparation: boiled eggs (hot), hard boiled eggs (cold), fried eggs, scrambled eggs, poached eggs, omelettes, scotch eggs, quiches/savoury flans, egg mayonnaise, egg sandwiches, egg salad, custards, meringues, sweet flan/crème caramel, duck/quail's eggs, raw eggs, egg yolk separate from the white, and egg white separate from the yolk. Participants were asked to report frequency of consumption on a seven point scale of 'more than once a day', 'more or less daily', '3-5 days a week', '1-2 days a week', '1-3 days a month', 'less than monthly', and 'never'. FFQs have previously been demonstrated as valid measures of food intake in older individuals $[45,46]$. 
Protein Intake: The same FFQ measures were used to assess participants' habitual intake of a list of 18 other protein-containing foods: white meat (e.g., chicken, turkey); red meat (e.g., beef, lamb, pork); processed meat (e.g., ham, bacon, sausages, corned beef); white fish (e.g., cod, haddock); oily fish (e.g., sardines, salmon); seafood (e.g., prawns, mussels, crab); vegetarian meat substitutes (e.g., Quorn); milk in coffee or tea; milk (excluding milk in tea/coffee); yoghurt, custards, blancmanges, etc.; hard cheeses (e.g., Cheddar, Stilton); soft cheeses (e.g., cream cheese, brie, cottage cheese); nuts and seeds; pulses (e.g., lentils, Dahl); beans or peas; bread (e.g., white or whole meal); and breakfast cereals or porridge. Intakes of other protein-containing foods were assessed to allow consideration of regular protein intakes in our analyses. The foods were selected based on other studies [35] and the sources of protein contributing most to protein intake in British older adults in the National Diet and Nutrition Survey (NDNS) data [29].

Reasons for eating or not eating eggs: The series of statements on reasons for eating/not eating eggs included at least one statement for each of the 69 reasons previously identified [44], resulting in a total of 76 statements. Seven reasons were queried using several statements because they referred to a combination of slightly different topics. For example, the reason 'recommendations' was represented with three statements relating to: recommendations from the media, recommendations from friends and family, and recommendations from health professionals. Nineteen statements were also repeated for 'my favourite type of egg' as well as given for 'eggs' in general. Eggs can be consumed using a number of different preparations and it was recognised that some of the reasons given for eating eggs in the qualitative work may be more relevant for some preparations than others. For example, the reason 'effort to prepare' may be low for eggs in general compared to other protein-rich foods, but may also be high for 'omelettes' compared to 'raw eggs'. These questions were asked for 'my favourite type of egg' as opposed to all preparations to avoid participant burden, but participants were asked to indicate their favourite egg preparation. All statements were responded to on a five point Likert scale using the answer options: 'strongly disagree', 'disagree', 'neither disagree nor agree', 'agree', and 'strongly agree'. For all statements, special attention was paid to the wording of the statements, through reference to the focus group transcripts [44], for the language used by the target population.

Demographic and lifestyle characteristics: Questions on demographic characteristics requested: gender; age group; height and weight (converted to Body Mass Index (BMI)); marital status; living status; (first half of) postcode; education level (total number of years); nationality; and most recent level of employment. Lifestyle factors requested were: allergies to eggs; conditions that may have changed eating behaviour (e.g., chemo/radiotherapy) in the last 6 months; difficulties with everyday activities (measured using an adapted version of the SARC-F questionnaire to give an indication of frailty or sarcopenia [47]); help received with food shopping or preparation; food deliveries or eating out or away from home; denture wearing; and food neophobia (a reluctance to try new foods) [48,49]. These demographic and lifestyle characteristics have previously been associated with food intake in older individuals, e.g., [27,31-35,48,49].

Prior to administration, a pilot study was performed to test the questionnaire for face validity and internal reliability. Fifteen individuals from the target age group were asked to complete the questionnaire in the presence of the researcher, while simultaneously providing observations and questions in a 'think aloud' style [50]. Question statements and formatting were refined during and following piloting to increase clarity.

\subsection{Questionnaire Administration}

The questionnaire was sent by post to a National sample of 1000 community-dwelling adults over 55 years old. The sample was representative of the number of males and females per 5 year age group living in each different area of the UK, as reported in the UK Census 2011 [51]. Names and addresses were obtained from the data sampling company Sample Answers, London, UK. An additional 82 questionnaires were also sent out to a National sample of people aged over 55 years old who had taken part in previous studies and indicated that they would be willing to be contacted again. 
All individuals were living in their own homes at the time of questionnaire administration. A total of 588 participants were pre-notified by telephone with a brief conversation or voicemail message announcing that a questionnaire would arrive at their address soon. Reminders were sent out to non-responders about 6 weeks and 6 months after posting the first questionnaire.

\subsection{Analyses}

First, questionnaires from respondents with allergies to eggs, or who had had conditions that had changed their eating behaviour in the last 6 months were excluded. Remaining questionnaires were then screened for missing and inappropriate values. If responses for habitual egg intake and the reasons for eating eggs were missing by more than $20 \%$ per respondent, this individual's data were excluded from analyses. If $80 \%$ or more questions were completed, missing values were completed with the value for 'neither disagree nor agree', or an average score if two answers had been given. If responses for habitual egg intake were greater than three standard deviations above the mean, these participants were also excluded.

Gender, age and location for the sample were then examined using $\chi^{2}$ tests to assess whether the sample for analysis was representative of the British population over 55 years old according to the UK Census 2011 [51].

Multiple linear regression analyses were then used to predict habitual egg intakes using all reasons for eating/not eating eggs, taking into account demographic and lifestyle characteristics, including intake from other protein-containing foods.

Egg FFQ data were converted to one number representing number of eggs eaten per month, where the category 'more than once a day' was counted as 60 times per month, 'more or less daily' was counted as 30 times, ' $3-5$ days a week' as 16 times, ' $1-2$ days a week' as 6 times, ' $1-3$ days a month' as 2 times, 'less than monthly' as 0.5 times, and 'never' was counted as 0 times per month, for all dishes excepting egg mayonnaise, custards, meringues, and sweet flan/crème caramel. Responses to egg mayonnaise were discounted due to their small and inconsistent contribution to total egg intakes based on portion size and amount per portion (the question was useful and retained in the questionnaire for reasons of face validity) [29]. For the sweet dishes, each consumption was counted as 0.5 portions, because a standard portion tends to amount to less than one egg [29]. Protein FFQ data were converted similarly for all foods with the exception of milk in coffee or tea, which was included as 0.2 portions each time it was consumed [29].

Responses to all statements on reasons for eating/not eating eggs were coded from 1: 'strongly disagree' to 5: 'strongly agree'. Considering the large number of statements (76 statements), a Principal Component Analysis (PCA) was then conducted to reduce the number of variables to be included in subsequent regression models [52]. The PCA was conducted on all suitable data collected from the initial administration and 6 week reminders of the questionnaire $(n=182)$, using an orthogonal rotation and varimax method [53]. To avoid over reduction, all components with an eigenvalue $>1$ were considered, and component loadings were used together with semantic reasoning to identify the contributors to each component. Component scores were then generated per individual by adding all relevant items. The PCA was conducted using all statements relating to 'eggs' in general. Only 102 participants completed the questions on 'my favourite type of egg'. Due to this low response rate, these items were not considered further for analysis.

Significant demographic and lifestyle characteristics in this sample were also identified in advance of the main analyses using multiple linear regression, where habitual egg intake was predicted by all demographic and lifestyle characteristics, including intake from other protein-containing foods. This analysis was done in advance of the main analyses to maintain good power in the main analyses [52].

Finally, multiple linear regression analyses were undertaken to predict habitual egg intakes using all calculated PCA components, taking into account significant demographic and lifestyle characteristics. Data analyses were performed using IBM SPSS Statistics software version 22.0 (IBM, Armonk, NY, USA). 


\section{Results}

\subsection{Respondents}

A total of 259 individuals returned the questionnaire (24\% response rate). Of these, 29 questionnaires were excluded based on the presence of allergies, medical conditions and/or missing values. Demographic information for the remaining 230 respondents is given in Table 1.

Table 1. Participant characteristics $(n=230)$.

\begin{tabular}{|c|c|c|}
\hline Characteristic & & Value \\
\hline \multirow{6}{*}{ Age } & 55-59 years old & $32(13.8 \%)$ \\
\hline & 60-64 years old & $38(16.4 \%)$ \\
\hline & 65-69 years old & $54(23.3 \%)$ \\
\hline & 70-74 years old & $48(20.7 \%)$ \\
\hline & $75-79$ years old & $36(15.5 \%)$ \\
\hline & $80+$ years old & $22(9.5 \%)$ \\
\hline \multirow{2}{*}{ Gender* } & Male & $119(51.3 \%)$ \\
\hline & Female & $110(47.4 \%)$ \\
\hline \multirow{12}{*}{ Region } & Scotland & $11(4.7 \%)$ \\
\hline & Northern Ireland & $5(2.2 \%)$ \\
\hline & North East & $6(2.6 \%)$ \\
\hline & North West & $22(9.5 \%)$ \\
\hline & Yorkshire and the Humber & $21(9.1 \%)$ \\
\hline & East Midlands & $18(7.8 \%)$ \\
\hline & West Midlands & $14(6.0 \%)$ \\
\hline & Wales & $9(3.9 \%)$ \\
\hline & East of England & $17(7.3 \%)$ \\
\hline & London & $17(7.3 \%)$ \\
\hline & South East & $35(15.1 \%)$ \\
\hline & South West & $53(22.8 \%)$ \\
\hline \multirow{4}{*}{ Marital status * } & Married & $149(64.2 \%)$ \\
\hline & Divorced & $28(12.1 \%)$ \\
\hline & Widowed & $33(14.2 \%)$ \\
\hline & Never married & $17(7.3 \%)$ \\
\hline \multirow{2}{*}{ Living status * } & Alone & $66(28.4 \%)$ \\
\hline & With others & $161(69.4 \%)$ \\
\hline Education in years (Mean \pm standard deviation (SD)) & & $13 \pm 2$ \\
\hline \multirow{4}{*}{ Most recent employment level * } & Unemployed & $11(4.7 \%)$ \\
\hline & Manual worker & $44(19.0 \%)$ \\
\hline & Non-manual worker & $86(37.1 \%)$ \\
\hline & Professional/Management & $86(37.1 \%)$ \\
\hline Body Mass Index (BMI) in kg $/ \mathrm{m}^{2}($ Mean $\pm \mathrm{SD})$ & & $27 \pm 5$ \\
\hline \multirow{3}{*}{ Denture wearing * } & No & $156(67.2 \%)$ \\
\hline & Partial dentures & $55(23.7 \%)$ \\
\hline & Full dentures & $17(7.3 \%)$ \\
\hline \multirow{3}{*}{ Receiving help with food shopping * } & Never & $200(86.2 \%)$ \\
\hline & Sometimes & $19(8.2 \%)$ \\
\hline & Often & $9(3.9 \%)$ \\
\hline \multirow{3}{*}{ Receiving help with food preparing * } & Never & $203(87.5 \%)$ \\
\hline & Sometimes & $17(7.3 \%)$ \\
\hline & Often & $8(3.4 \%)$ \\
\hline \multirow{3}{*}{ Eating out or away from home* } & Never & $12(5.2 \%)$ \\
\hline & Sometimes & $145(62.5 \%)$ \\
\hline & Often & $68(29.3 \%)$ \\
\hline \multirow{3}{*}{ Getting food delivered * } & Never & $162(69.8 \%)$ \\
\hline & Sometimes & $55(23.7 \%)$ \\
\hline & Often & $11(4.7 \%)$ \\
\hline \multirow{6}{*}{ Physical disabilities * } & No & $169(72.8 \%)$ \\
\hline & Some difficulties with some activities & $33(14.2 \%)$ \\
\hline & Some difficulties with all activities & $10(4.3 \%)$ \\
\hline & A lot of difficulty with some activities & $7(3.0 \%)$ \\
\hline & A lot of difficulty with all activities & $4(1.7 \%)$ \\
\hline & Unable to do activities & $1(0.4 \%)$ \\
\hline Food Neophobia score (Mean \pm SD) & & $25 \pm 7$ \\
\hline
\end{tabular}

* Frequency and percentage are given. For several variables the numbers do not add up to $n=230$ because different people left different questions open. 
The sample was representative of the UK Census 2011 in terms of gender $\left(\chi^{2}(1)=2.97, p>0.05\right)$, but 55-59 year old and 80+ year groups were under represented, while the 65-69 year old, 70-74 year old, and 75-79 year old groups were over represented $\left(\chi^{2}(6)=37.36, p<0.05\right)$, and for location, Scotland was under represented, and the South West was over-represented $\left(\chi^{2}(12)=60.15, p<0.05\right)$.

\subsection{Egg Intake}

Habitual egg intake for the sample ranged from 1-89 eggs/month with a mean (SD) of 18 (13) eggs/month.

\subsubsection{Reasons for Egg Consumption—Principal Components Analysis}

The PCA resulted in 23 factors explaining $69.9 \%$ of the variance. These 23 components were titled: liking/flavour/variety; value for money; food chain; everyday food; effort; previous experience; past; occasion; stereotypes; sensory; expectations; willingness to eat more eggs; external reports; eating less with aging; medical factors; time; social environment; non-habitual intake; moreish; suitability; familiarity; size; and food safety. Contributing reasons and definitions are given in Table 2. Minimum, maximum, mean and SD for all component scores are given in Table 3. Component scores in the final sample showed no multicollinearity (largest $r=0.60, p<0.01$ ). 
Table 2. Principal Component Analysis: Component definition and contributing reasons.

\begin{tabular}{|c|c|c|}
\hline Component & Included Reasons & Definition \\
\hline Liking/flavour/variety $(\alpha=0.795)$ & Variety; Balanced diet; Flavour; Liking & Whether people like the taste of eggs, and think they add variety to the diet (in terms of taste). \\
\hline Value for money $(\alpha=0.715)$ & $\begin{array}{l}\text { Spoilage and wastage (R); Versatility; Standby; Cost; Value; } \\
\text { Planning; Complete; Substantial meal; Value for money; } \\
\text { Financial situation (R); Nutritional knowledge }\end{array}$ & $\begin{array}{l}\text { Whether people think eggs provide good value for the money you pay for them, including eggs being a good value } \\
\text { food, which is cheap and does not go off quickly (not wanting to waste money). }\end{array}$ \\
\hline Food chain $(\alpha=0.767)$ & $\begin{array}{l}\text { Processing; Freshness; Animal welfare; Wide variety of choice; } \\
\text { Quality; Food origin }\end{array}$ & $\begin{array}{l}\text { The importance of knowing about the food chain for the egg, from chicken (animal welfare) to shop to plate, and } \\
\text { the quality/freshness of the egg as a result of this. }\end{array}$ \\
\hline Everyday food $(\alpha=0.686)$ & $\begin{array}{l}\text { Convenience; Satiating effect; Habit (R); Staple food; } \\
\text { Recommendations -friends/family; Digestibility }\end{array}$ & $\begin{array}{l}\text { Whether people think eggs are a convenient filling staple food and eat them habitually (including how much this is } \\
\text { affected by recommendations from family and friends). }\end{array}$ \\
\hline Effort $(\alpha=0.700)$ & $\begin{array}{l}\text { Practicalities; Effort to prepare; Politeness; Health beliefs; } \\
\text { Culinary skills; Eating abilities; Availability served by others }\end{array}$ & $\begin{array}{l}\text { Whether people think eggs take a lot of effort to prepare, or eat, and would be eaten out of politeness or only when } \\
\text { they are served by others. Also, including how healthy people think eggs are. }\end{array}$ \\
\hline Previous experience $(\alpha=0.524)$ & Genes; Previous experience; Medical factors general & $\begin{array}{l}\text { Whether people have had a bad experience in the past, or have a family history of problems related to eating eggs, } \\
\text { or a medical condition that restricts them from eating eggs. }\end{array}$ \\
\hline Past $(\alpha=0.595)$ & Trend availability; Trend popular (R); Upbringing & $\begin{array}{l}\text { Whether people had many eggs and remember many people eating them in the past, and/or remember being } \\
\text { brought up with eggs. }\end{array}$ \\
\hline Occasion $(\alpha=0.521)$ & Comfort; Experience & Whether people eat eggs when there is a particular occasion. \\
\hline Stereotypes $(\alpha=0.565)$ & Masculinity; Environmental issues; Status personal; Femininity & Amount of agreement with stereotypes or perceptions about a certain type of person who eats eggs. \\
\hline Sensory $(\alpha=0.611)$ & Odour; Appearance; Texture & Whether people eat eggs for their sensory aspects. \\
\hline Expectations $(\alpha=0.544)$ & Combination; Status guests; Appeal & $\begin{array}{l}\text { How eggs are likely to be eaten in certain circumstances, whether they are suitable with other foods or in certain } \\
\text { circumstances, e.g., at a dinner party. }\end{array}$ \\
\hline $\begin{array}{l}\text { Willingness to eat more eggs } \\
(\alpha=0.485)\end{array}$ & Sufficiency; Replacing foods & Having clear ideas about the amounts/portions of eggs that are enough, willingness to add more eggs to the diet. \\
\hline External reports $(\alpha=0.483)$ & $\begin{array}{l}\text { Recommendations media; Food scares (R); Recommendations } \\
\text { health professionals (R) }\end{array}$ & How seriously people take external reports and recommendations about eggs and health. \\
\hline Eating less with aging $(\alpha=0.516)$ & $\begin{array}{l}\text { Appetite (R); Sensory abilities; Restraint; Physical abilities } \\
\text { shopping; Physical abilities preparing (R) }\end{array}$ & $\begin{array}{l}\text { Whether people suffer from different struggles/problems that may occur when getting older, like physical abilities } \\
\text { that hinder shopping or preparing foods, or loss of appetite or sensory deterioration. }\end{array}$ \\
\hline Medical factors $(\alpha=0.564)$ & Medical factors cholesterol; Medical factors heart disease & Whether people believe eating eggs increases cholesterol or risk of heart disease. \\
\hline Time $(\alpha=0.448)$ & Time to prepare; Availability & Whether people perceive eggs as quick to prepare and usually available. \\
\hline Social environment $(\alpha=0.207)$ & Culture; Other people present; Moral values (R) & Whether people believe eating eggs are part of their society or culture. \\
\hline Non-habitual intake $(\alpha=0.219)$ & Trying new things (R); Treat & Whether people are willing to consider trying new recipes or would consider eggs as treats. \\
\hline Moreish $($ PCA loading $=0.703$ ) & Moreish & Whether people perceive eggs as moreish. \\
\hline Suitability (PCA loading = 0.744$)$ & Suitability & $\begin{array}{l}\text { How suitable it is to eat eggs in a certain context, situation, time, dish, etc. Ideas on how you are supposed to eat } \\
\text { them. }\end{array}$ \\
\hline Familiarity (PCA loading $=0.796)$ & Familiarity & The importance of egg dishes people have never tried. \\
\hline Size $(\mathrm{PCA}$ loading $=0.764)$ & Size & Whether the size of an egg matters. \\
\hline Food Safety $($ PCA loading $=0.749)$ & Food safety & How perceived food safety affects egg intake. Agreement to only eating eggs when they are properly cooked. \\
\hline
\end{tabular}


Table 3. Minimum, maximum, mean and SD for each component for all participants $(n=230)$. Component scores were converted to scores ranging $1-5$, to allow comparability with the initial questionnaire response format and coding.

\begin{tabular}{ccccc}
\hline & Minimum & Maximum & Mean & SD \\
\hline Liking/Flavour/Variety & 1.00 & 5.00 & 4.03 & 0.55 \\
Value for money & 2.55 & 5.00 & 3.89 & 0.37 \\
Food chain & 2.17 & 5.00 & 3.70 & 0.60 \\
Everyday food & 1.00 & 5.00 & 3.54 & 0.58 \\
Effort & 1.00 & 4.00 & 2.13 & 0.45 \\
Previous experience & 1.00 & 3.67 & 1.68 & 0.57 \\
Past & 1.00 & 4.33 & 2.20 & 0.80 \\
Occasion & 1.00 & 5.00 & 2.28 & 0.81 \\
Stereotypes & 1.00 & 4.00 & 1.93 & 0.55 \\
Sensory & 1.67 & 5.00 & 3.32 & 0.57 \\
Expectations & 1.00 & 5.00 & 2.17 & 0.70 \\
Willingness to eat more eggs & 1.00 & 4.50 & 2.72 & 0.72 \\
External reports & 1.00 & 4.67 & 2.37 & 0.68 \\
Eating less with aging & 1.00 & 4.00 & 2.23 & 0.55 \\
Medical factors & 1.00 & 4.50 & 2.68 & 0.80 \\
Time & 1.50 & 5.00 & 4.08 & 0.66 \\
Social environment & 1.00 & 4.33 & 2.81 & 0.57 \\
Non-habitual intake & 1.00 & 5.00 & 2.85 & 0.78 \\
Moreish & 1.00 & 5.00 & 1.98 & 0.89 \\
Suitability & 1.00 & 5.00 & 3.31 & 0.92 \\
Familiarity & 1.00 & 5.00 & 3.69 & 0.74 \\
Size & 1.00 & 5.00 & 3.22 & 1.10 \\
Food safety & 1.00 & 5.00 & 3.76 & 0.91 \\
\hline
\end{tabular}

\subsubsection{Demographic and Lifestyle Characteristics-Initial Analysis}

Living status and marital status were highly correlated $(r=0.70, p<0.01)$, so only living status was included in regression models. No other evidence of multicollinearity was found (largest $r=0.56$, $p<0.01)$. The multiple linear regression model including all demographic characteristics and lifestyle factors significantly predicted egg intake $\left(r=0.41, r^{2}=0.17\right.$, adjusted $r^{2}=0.10, \mathrm{~F}(15,217)=2.69$, $p<0.01)$. Egg intake was significantly associated with a higher intake of other protein-containing foods $(\beta=0.31, p<0.01)$, a younger age $(\beta=-0.16, p=0.04)$, and a higher BMI $(\beta=0.16, p=0.02)$. All standardised co-efficients ( $\beta$ values) and $p$ values can be found in Table 4 .

Table 4. Outcomes of the multiple linear regression model assessing the effect of demographic characteristics and lifestyle factors on egg intake. Significant effects are given in bold $(p<0.05)$.

\begin{tabular}{ccc}
\hline & $\boldsymbol{\beta}$ & $\boldsymbol{p}$-Value \\
\hline Protein intake frequency per month & $\mathbf{0 . 3 0 7}$ & $<\mathbf{0 . 0 1}$ \\
Physical ability score & 0.128 & 0.17 \\
Food neophobia score & -0.093 & 0.18 \\
Receiving help with food shopping & -0.056 & 0.56 \\
Receiving help with food preparing & -0.129 & 0.12 \\
Eating out or away from home & 0.019 & 0.78 \\
Getting food delivered & 0.024 & 0.73 \\
Age group & $-\mathbf{0 . 1 5 5}$ & $\mathbf{0 . 0 4}$ \\
Gender & -0.079 & 0.25 \\
Body Mass Index (BMI) & $\mathbf{0 . 1 5 7}$ & $\mathbf{0 . 0 2}$ \\
Region code & -0.042 & 0.54 \\
Living status & -0.120 & 0.09 \\
Years of education & -0.128 & 0.08 \\
Employment level & 0.029 & 0.69 \\
Denture wearing & 0.119 & 0.10 \\
\hline
\end{tabular}


3.2.3. Egg Intake, Reasons for Egg Intake and Significant Demographic and Lifestyle Characteristics

The final regression model significantly predicted egg consumption $\left(r=0.60, r^{2}=0.36\right.$, adjusted $\left.r^{2}=0.28, F(26,218)=4.20, p<0.01\right)$. Greater egg intakes were significantly associated with: greater liking and/or greater agreement that eggs are tasty and add variety to the diet $(\beta=0.22, p=0.02)$; less agreement that eggs are good value for money $(\beta=-0.25, p<0.01)$; higher agreement that eggs are an everyday type of food $(\beta=0.23, p=0.01)$; less agreement that a certain type of person eats eggs $(\beta=-0.20, p=0.01)$; greater agreement that eggs should be eaten in certain circumstances ( $\beta=0.17, p=0.02$ ); lower willingness to increase egg intake (or greater agreement that sufficient quantities of eggs are already consumed) $(\beta=-0.16, p=0.01)$; greater agreement with eating less with aging $(\beta=0.25, p<0.01)$; lower agreement that eggs may increase cholesterol or risk of heart disease $(\beta=-0.15, p=0.03)$; greater agreement with eating eggs as a treat and trying new recipes with eggs ( $\beta=0.14, p=0.04)$; greater difficulty stopping eating eggs once started $(\beta=0.16, p=0.02)$; greater consumption of other protein-containing foods $(\beta=0.24, p<0.01)$; a younger age $(\beta=-0.16, p=0.02)$; and a higher BMI $(\beta=0.14, p=0.03)$. All standardised coefficients ( $\beta$ values) and $\mathrm{p}$ values can be found in Table 5.

Table 5. Outcomes of the multiple linear regression model assessing the effect of the PCA components, and protein intake, age group and BMI, on egg intake. BMI was imputed with the mean, where necessary. Significant effects are given in bold $(p<0.05)$.

\begin{tabular}{ccc}
\hline & $\beta$ & $p$-Value \\
\hline Liking/Flavour/Variety & $\mathbf{0 . 2 1 6}$ & $\mathbf{0 . 0 2}$ \\
Value for money & $-\mathbf{0 . 2 5 4}$ & $<\mathbf{0 . 0 1}$ \\
Food chain & 0.099 & 0.16 \\
Everyday food & $\mathbf{0 . 2 2 6}$ & $\mathbf{0 . 0 1}$ \\
Effort & -0.147 & 0.08 \\
Previous experience & 0.125 & 0.09 \\
Past & 0.036 & 0.60 \\
Occasion & 0.078 & 0.27 \\
Stereotypes & $\mathbf{0 . 1 9 7}$ & $\mathbf{0 . 0 1}$ \\
Sensory & 0.030 & 0.72 \\
Expectations & $\mathbf{0 . 1 7 0}$ & $\mathbf{0 . 0 2}$ \\
External reports & $-\mathbf{0 . 1 6 1}$ & $\mathbf{0 . 0 1}$ \\
Eating less with aging & -0.126 & 0.08 \\
Medical factors & $\mathbf{0 . 2 5 0}$ & $<\mathbf{0 . 0 1}$ \\
Time & $-\mathbf{0 . 1 5 0}$ & $\mathbf{0 . 0 3}$ \\
Willingness to eat more eggs & 0.017 & 0.83 \\
Social environment & 0.011 & 0.87 \\
Non-habitual intake & $\mathbf{0 . 1 4 2}$ & $\mathbf{0 . 0 4}$ \\
Moreish & $\mathbf{0 . 1 6 0}$ & $\mathbf{0 . 0 2}$ \\
Suitability & 0.013 & 0.83 \\
Familiarity & -0.057 & 0.37 \\
Size & -0.042 & 0.51 \\
Food safety & -0.060 & 0.36 \\
Age group & $\mathbf{0 . 2 3 8}$ & $<\mathbf{0 . 0 1}$ \\
BMI & $\mathbf{0 . 1 5 5}$ & $\mathbf{0 . 0 2}$ \\
Protein intake frequency & $\mathbf{0 . 1 4 2}$ & $\mathbf{0 . 0 3}$ \\
\hline & &
\end{tabular}

\section{Discussion}

This work was conducted to elicit the most important challenges or facilitators associated with habitual egg intake in the older population, with a view to suggesting interventions to increase egg intakes in this group. Many challenges/facilitators were found, alongside associations with three demographic/lifestyle variables.

Strongest associations were found between a higher habitual egg intake and greater liking and/or greater agreement that eggs are tasty and add variety to the diet, higher agreement that eggs are an 
everyday type of food, less agreement that a certain type of person eats eggs and greater agreement with eating less with aging. Liking and flavour are known important determinants of eating behaviour in the elderly for a range of foods [34,54-56]. Variety is also well known to increase food intake [57-61]. Associations between egg intake and consideration of eggs as an everyday type of food are also unsurprising. Studies in younger adults have reported that eggs are considered a staple food [40,62] and in the UK in the 1960s, eggs were advertised using the slogan 'Go to work on an egg' [63], possibly aiding this perception in the current older population. Less agreement that a certain type of person eats eggs may also be linked to consideration of eggs as an everyday food. Alternatively, however, the stereotypes associated with egg consumption can be varied, ranging from consideration of eggs as a working class and masculine food, to a light and more feminine food [44,64]. Consumption of eggs was higher in those with less firm stereotypes. Older people have also previously been found to worry about consumption stereotypes [65], so less agreement with stereotypes may be preferable. Associations between egg consumption and eating less with ageing are also unsurprising. These findings suggest that older adults with more age-related difficulties with food preparation and shopping, or age-related deteriorations in sensory abilities and/or appetite tend to eat more eggs, and support suggestions that compared to other protein-rich foods, eggs may be particularly suitable for older adults with sensory or physical impairments $[4,27,28,34,35]$.

Interventions that focus on existing challenges or facilitators will likely have increased impact [42,43]. These results then suggest that strategies to increase egg consumption should focus on: improving liking, tastiness and adding variety; promoting eggs as an everyday type of food; reducing stereotypes about who does and who does not consume eggs; and promoting eggs for people who have noticed the effects of ageing on their food intake. Studies have shown that improving flavour by adding spices, flavour enhancers or sauces can increase intakes of protein-rich foods in older adults [66-69]. The use of several different added flavours also provides the possibility of increasing the hedonic variety of the diet, and increasing variety has been found to increase intake in older adults [58]. The promotion of foods based on their sensory characteristics, such as taste and texture, is also a well-used strategy known to result in changes in food intakes [70-72]. Associations with agreement that eggs are an everyday type of food would suggest a benefit from promoting eggs in this manner. This type of promotion may benefit from focus on the flexibility, easy to use, easy storage and long shelf life of eggs [40,41]. Studies also show that changing perceptions of those who eat and do not eat certain foods can change attitudes and behaviours towards those foods [73,74]. Although stereotypes can be resistant to change in the natural environment [75], interventions using social norms and strategies like social modelling have been successful at changing eating behaviours in younger individuals $[73,74]$. Some sensitivity, however, may be required when promoting foods specifically for ageing individuals or individuals with disabilities. Many older individuals may not think of themselves as old, or may not like to think of themselves as in need of special consideration [76,77]. For these individuals, the promotion of eggs as a food suitable for ageing individuals may even be counterproductive. Given these considerations and the above concern for broadening or reducing stereotypes, greater success may be achieved by promoting eggs for all, based on taste, variety and everyday use, as above.

The association between habitual egg intake and less agreement that eggs are good value for money is surprising. Eggs have previously been suggested as good value for money based on protein quality and cost $[37,38,40,41]$, and previous reports suggest that value for money can be an important determinant of food choice in older individuals $[35,55,61]$. It is unlikely that individuals who consume a lot of eggs are not aware of their value or cost, but it is possible that these individuals do not want to admit value- or cost-based judgements or do not want to be perceived as consuming eggs for valueor cost-based reasons. These findings would suggest that strategies that promote value-for-money may be counterproductive. Interestingly furthermore, when an exploratory regression analysis was undertaken involving only the component 'value for money', the model did not significantly predict egg intake $\left(r=0.074, r^{2}=0.005\right.$, adjusted $\left.r^{2}=0.001, F(1228)=1.24, p=0.27\right)$, suggesting that value for 
money only significantly explains variance in egg intake when the variance explained by the other components is also considered.

Smaller associations were also found between habitual egg intake and greater agreement that eggs should be eaten in certain circumstances or with certain other foods, lower willingness to increase egg intake (or greater agreement that sufficient quantities of eggs are already consumed), lower agreement that eggs are associated with cholesterol and cardiovascular disease risk, greater agreement that eggs can be consumed in a non-habitual manner, e.g., as treats, and greater difficulty stopping eating eggs once started. Findings related to expectations that eggs should be consumed in certain circumstances or with certain other foods are also possibly linked to perceptions of eggs as everyday foods (eggs may not be suitable for dinner parties), or the usual consumption of eggs in a familiar or habitual manner. Food intake can be strongly affected by familiarity and habit in older individuals $[34,36,78]$. These associations may again suggest the promotion of eggs as an everyday, familiar food. Associations, however, were also found between high egg intake and greater agreement with consuming eggs in a non-habitual manner, e.g., as treats. These findings may suggest that there are two different types of high egg consumer-those who consume a lot of eggs on a habitual basis in specific (regular) circumstances and those who consume a lot of eggs as a result of the use of eggs in a lot of dishes and recipes. Agreement with the consumption of eggs in a non-habitual manner would suggest benefit from recipes for novel dishes, coupled particularly with suggestions to increase taste, flavour and variety, to encourage egg intakes in older adults. To include those who prefer a more habitual consumption, simple everyday recipes that involve well known combinations of eggs and other foods, such as bacon or ham in the UK, may be particularly successful. Findings related to lower agreement that eggs may increase cholesterol or risk of heart disease suggest that recent scientific evidence and guidelines against restricting egg consumption [79-81] are well known (and/or may be better known in those who consume a lot of eggs), or that those who consume large amounts of eggs failed to acknowledge any previous association, possibly as a result of consuming high quantities of eggs and suffering no health complaints themselves. Various work suggests that older individuals can be less easily swayed by 'official information', and can rely more on their own opinions and experiences [82]. These findings suggest that campaigns that continue to address misconceptions that eggs are associated with specific health risks may be beneficial. Findings in relation to a lower willingness to increase egg consumption and greater difficulties stopping eating eggs once started are most likely reversed associations where a high egg consumption results in, as opposed to results from, a lower willingness to increase intakes and a suggestion that it is difficult to stop eating eggs once started.

We also found associations between a higher egg consumption and a higher intake of other protein-containing foods, a younger age, and a higher BMI. These findings suggest that people tend to have either a high intake or low intake of a number of protein-containing foods, including eggs $[38,83,84]$, and strategies to increase protein intake will undoubtably benefit from encouraging intake of a number of protein-rich foods. The consideration of foods or food components that have been linked to increased health risk, such as processed meats, however, would suggest that strategies that focus on replacing some of these other protein-containing foods, e.g., with eggs, may also be helpful. Increased consumption of protein-rich foods by those of a younger age, within the older population, has previously been reported $[4,30,32,35]$, and attributed to increased abilities or increased nutritional knowledge in younger individuals [30,32,35]. Associations between egg intake and BMI and a high energy intake have also previously been reported $[83,84]$, although the direction or underlying cause of any association remains unclear [83-86]. While explanations cannot be disentangled here, strategies aiming to promote eggs to older individuals and to leaner individuals may have an increased chance of benefit on a population-wide basis.

Strengths of our study include the use of a wide population from across the UK and a wide variety of consumers, and the reporting of variable amounts of egg consumption across the sample. The sample was representative of the UK older population based on gender. The under-representation of 55-59 and 80+ years old is likely due to a lack of free time, frailty, and physical or visual impairment. 
Under-representation of age at both ends of our age range, however, suggests that this is unlikely to have affected our results. The over-representation of individuals in the South West where Bournemouth University is based, and under-representation of Scotland, is also unlikely to have greatly affected our results as egg consumption and attitudes do not differ markedly between regions (personal communication with British Egg Industry Council). Our study is limited by our use of an FFQ to measure intakes of both eggs and protein-containing foods. Frequency measures are commonly used, and have been shown to be valid measures of intake in the elderly $[45,46,87,88]$, but portion sizes were not given nor was it possible to indicate or calculate the number of eggs or amount of protein provided per food item. This may have resulted in differences between respondents in interpretation, but these differences are unlikely to have been systematic. Our final analyses are also limited by the low reliability of some of the components generated by the Principal Component Analysis (Cronbach's alphas were below 0.5 for five of the 23 generated components). This suggests that the components 'Social environment', 'Time', and most notably, the components 'Non-habitual intake', 'Willingness to eat more' and 'Expectations' cannot be considered reliable in the current sample, and should be treated with caution.

\section{Conclusions}

In conclusion, many possibilities for future intervention based on existing challenges to or facilitators of egg consumption were found. Our results suggest that strategies to increase egg consumption should focus on: improving liking, tastiness and adding variety; promoting eggs as an everyday type of food; reducing stereotypes about who does and who does not consume eggs; and promoting eggs for people who have noticed the effects of ageing on their food intake. Strategies that highlight value-for-money may also be counterproductive. Future work evaluating the value of these strategies for increasing protein intake in this age group would clearly be of value.

Author Contributions: The study was initially conceived by K.M.A., and the conception refined by E.v.d.H. and J.L.M. Data collection, inputting and analysis were undertaken by E.v.d.H. The first draft of the manuscript was written by E.v.d.H. and refined by K.M.A. and J.L.M. All authors approved the final manuscript. Funding for the project was awarded to K.A. and J.M.

Funding: The studentship was funded by Bournemouth University, UK and the British Egg Industry Council, UK.

Acknowledgments: This work was undertaken by Emmy van den Heuvel, as part of a PhD studentship, supervised by Katherine. M. Appleton and Jane. L. Murphy. We are grateful to all participants who took part and to the independent Scientific Advisory Committee of the British Egg Industry Council for helpful comments on the study protocol and a draft of the final paper.

Conflicts of Interest: The authors declare no conflict of interest. The funders played no role in the design of the study, the interpretation of the results or the decision to publish.

\section{References}

1. Office for National Statistics. National Population Projections, 2012-Based Statistical Bulletin. Available online: https: / /www.ons.gov.uk/peoplepopulationandcommunity (accessed on 26 March 2018).

2. Wolfe, R.R.; Miller, S.L.; Miller, K.B. Optimal protein intake in the elderly. Clin. Nutr. 2008, 27, 675-684. [CrossRef] [PubMed]

3. Bauer, J.; Bioli, G.; Cederholm, T.; Cesari, M.; Cruz-Jentoft, A.J.; Morley, J.E.; Phillips, S.; Sieber, C.; Stehle, P.; Teta, D.; et al. Evidence-based recommendations for optimal dietary protein intake in older people: A position paper from the PROT-AGE Study Group. J. Am. Med. Dir. Assoc. 2013, 14, 542-559. [CrossRef] [PubMed]

4. Deutz, N.E.P.; Bauer, J.M.; Barazzoni, R.; Biolo, G.; Boirie, Y.; Bosy-Westphal, A.; Cederholm, T.; Cruz-Jentoft, A.; Krznariç, Z.; Nair, K.S.; et al. Protein intake and exercise for optimal muscle function with aging: Recommendations from the ESPEN Expert Group. Clin. Nutr. 2014, 33, 929-936. [CrossRef] [PubMed]

5. Imai, E.; Tsubota-Utsugi, M.; Kikuya, M.; Satoh, M.; Inoue, R.; Hosaka, M.; Metoki, H.; Fukushima, N.; Kurimoto, A.; Hirose, T.; et al. Animal protein intake is associated with higher-level functional capacity in elderly adults: The Ohasama Study. J. Am. Geriatr. Soc. 2014, 62, 426-434. [CrossRef] [PubMed] 
6. Beasley, J.M.; LaCroix, A.Z.; Neuhouser, M.L.; Huang, Y.; Tinker, L.; Woods, N.; Michael, Y.; Curb, J.D.; Prentice, R.L. Protein intake and incident frailty in the Women's Health Initiative observational study. J. Am. Geriatr. Soc. 2010, 58, 1063-1071. [CrossRef] [PubMed]

7. Kobayashi, S.; Asakura, K.; Suga, H.; Saski, S. The Three generation study of women on diets and health study group. High protein intake is associated with low prevalence of frailty among old Japanese women: A multi center cross sectional study. Nutr. J. 2013, 12, 164. [CrossRef] [PubMed]

8. Zoltick, E.S.; Sahni, S.; McLean, R.R.; Quach, L.; Casey, V.A.; Hannan, M.T. Dietary protein intake and subsequent falls in older men and women: The Framingham Study. J. Nutr. Health Aging 2011, 15, 147-152. [CrossRef] [PubMed]

9. Sahni, S.; Cupples, L.A.; McLean, R.R.; Tucker, K.L.; Broe, K.E.; Kiel, D.P.; Hannan, M.T. Protective effect of high protein and calcium intake on the risk of hip fracture in the Framingham offspring cohort. J. Bone Miner. Res. 2010, 25, 2770-2776. [CrossRef] [PubMed]

10. Dawson-Hughes, B. Interaction of dietary calcium and protein in bone health in humans. J. Nutr. 2003, 133, 852S-854S. [CrossRef] [PubMed]

11. Beasley, J.M.; LaCroix, A.Z.; Larson, J.C.; Huang, Y.; Neuhouser, M.L.; Tinker, L.F.; Jackson, R.; Snetselaar, L.; Johnson, K.C.; Eaton, C.B.; et al. Biomarker-calibrated protein intake and bone health in the Women's Health Initiative clinical trials and observational study. Am. J. Clin. Nutr. 2014, 99, 934-940. [CrossRef] [PubMed]

12. De Souza, G.P.; Martini, L.A. Effect of protein intake on bone and muscle mass in the elderly. Nutr. Rev. 2010, 68, 616-623. [CrossRef] [PubMed]

13. Rapuri, P.B.; Gallagher, J.C.; Haynatzka, V. Protein intake: Effects on bone mineral density and the rate of bone loss in elderly women. Am. J. Clin. Nutr. 2003, 77, 1517-1525. [CrossRef] [PubMed]

14. Nuttall, F.Q.; Gannon, M.C. The metabolic response to a high-protein, low-carbohydrate diet in men with type 2 diabetes mellitus. Metabolism 2006, 55, 243-251. [CrossRef] [PubMed]

15. Hu, F.B.; Stampfer, M.J.; Manson, J.E.; Rimm, E.; Colditz, G.A.; Speizer, F.E.; Hennekens, C.H.; Willett, W.C. Dietary protein and risk of ischemic heart disease in women. Am. J. Clin. Nutr. 1999, 70, 221-227. [CrossRef] [PubMed]

16. Stamler, J.; Elliott, P.; Kesteloot, H.; Nichols, R.; Claeys, G.; Dyer, A.R.; Stamler, R. Inverse relation of dietary protein markers with blood pressure. Findings for 10,020 men and women in the INTERSALT Study. Circulation 1996, 94, 1629-1634. [CrossRef] [PubMed]

17. Appel, L.J.; Sacks, F.M; Carey, V.J; Obarzanek, E.; Swain, J.F.; Miller, E.R.; Conlin, P.R.; Erlinger, T.P.; Rosner, B.A.; Laranjo, N.M.; et al. Effects of protein, monounsaturated fat, and carbohydrate intake on blood pressure and serum lipids: Results of the OmniHeart randomized trial. JAMA 2005, 294, 2455-2464. [CrossRef] [PubMed]

18. Stratton, R.J.; Ek, A.C.; Engfer, M.; Moore, Z.; Rigby, P.; Wolfe, R.; Elia, M. Enteral nutritional support in prevention and treatment of pressure ulcers: A systematic review and meta-analysis. Ageing Res. Rev. 2005, 4, 422-450. [CrossRef] [PubMed]

19. Schurch, M.A.; Rizzoli, R.; Slosman, D.; Vadas, L.; Vergnaud, P.; Bonjour, J.P. Protein supplements increase serum insulin-like growth factor-I levels and attenuate proximal femur bone loss in patients with recent hip fracture: A randomized, double-blind, placebo-controlled trial. Ann. Intern. Med. 1998, 128, 801-809. [CrossRef] [PubMed]

20. Hughes, M.S.; Kazmier, P.; Burd, T.A; Anglen, J.; Stoker, A.M.; Kuroki, K.; Carson, W.L.; Cook, J.L. Enhanced fracture and soft-tissue healing by means of anabolic dietary supplementation. J. Bone Joint Surg. Am. 2006, 88, 2386-2394. [CrossRef] [PubMed]

21. Beasley, J.M.; Shikany, J.M.; Thomson, C.A. The role of dietary protein intake in the prevention of sarcopenia of aging. Nutr. Clin. Pract. 2013, 28, 684-690. [CrossRef] [PubMed]

22. Houston, D.K.; Nicklas, B.J.; Ding, J.; Harris, T.B.; Tylavsky, F.A.; Newman, A.B.; Lee, J.S.; Sahyoun, N.R.; Visser, M.; Kritchevsky, S.B. Dietary protein intake is associated with lean mass change in older, community-dwelling adults: The Health, Aging and Body Composition (Health ABC) Study. Am. J. Clin. Nutr. 2008, 87, 150-155. [CrossRef] [PubMed]

23. Komar, B.; Schwingshackl, L.; Hoffmann, G. Effects of leucine-rich protein supplements on anthropometric parameter and muscle strength in the elderly: A systematic review and meta-analysis. J. Nutr. Health Aging 2015, 19, 437-446. [CrossRef] [PubMed] 
24. Beasley, J.M.; Wertheim, B.C.; LaCroix, A.Z.; Prentice, R.L.; Neuhouser, M.L.; Tinker, L.F.; Kritchevsky, S.; Shikany, J.M.; Eaton, C.; Chen, Z.; et al. Biomarker-Calibrated Protein Intake and Physical Function in the Women's Health Initiative. J. Am. Geriatr. Soc. 2013, 61, 1863-1871. [CrossRef] [PubMed]

25. Gregorio, L.; Brindisi, J.; Kleppinger, A.; Sullivan, R.; Mangano, K.M.; Bihuniak, J.D.; Kenny, A.M.; Kerstetter, J.E.; Insogna, K.L. Adequate dietary protein is associated with better physical performance among post-menopausal women 60-90 years. J. Nutr. Health Aging 2014, 18, 155-160. [CrossRef] [PubMed]

26. Malafarina, V.; Uriz-Otano, F.; Iniesta, R.; Gil-Guerrero, L. Effectiveness of nutritional supplementation on muscle mass in treatment of sarcopenia in old age: A systematic review. J. Am. Med. Dir. Assoc. 2013, 14, 10-17. [CrossRef] [PubMed]

27. Nieuwenhuizen, W.F.; Weenen, H.; Rigby, P.; Hetherington, M.M. Older adults and patients in need of nutritional support: Review of current treatment options and factors influencing nutritional intake. Clin. Nutr. 2010, 29, 160-169. [CrossRef] [PubMed]

28. Volpi, E.; Campbell, W.W.; Dwyer, J.T.; Johnson, M.A.; Jensen, G.L.; Morley, J.E.; Wolfe, R.R. Is the optimal level of protein intake for older adults greater than the recommended dietary allowance? J. Gerontol. A Biol. Sci. Med. Sci. 2013, 68, 677-681. [CrossRef] [PubMed]

29. National Diet and Nutrition Survey Results from Years 1, 2, 3 and 4 (combined) of the Rolling Programme (2008/2009-2011/2012): A Survey Carried Out on Behalf of Public Health England and the Food Standards Agency. Available online: https://assets.publishing.service.gov.uk/government/uploads/system/uploads/ attachment_data/file/594361/NDNS_Y1_to_Y4_UK_report_full_text_revised_February_2017.pdf (accessed on 30 September 2018).

30. Fulgoni, V.L. Current protein intake in America: Analysis of the National Health and Nutrition Examination Survey, 2003-2004. Am. J. Clin. Nutr. 2008, 87, 1554S-1557S. [CrossRef] [PubMed]

31. Berner, L.A.; Becker, G.; Wise, M.; Doi, J. Characterization of dietary protein among older adults in the United States: Amount, animal sources, and meal patterns. J. Acad. Nutr. Diet 2013, 113, 809-815. [CrossRef] [PubMed]

32. Tieland, M.; Borgonjen-van den Berg, K.J.; van Loon, L.J.C.; de Groot, L.C. Dietary protein intake in community-dwelling frail and institutionalized elderly people: Scope for improvement. Eur. J. Nutr. 2012, 51, 173-179. [CrossRef] [PubMed]

33. Jyvakorpi, S.K.; Pitkala, K.H.; Puranen, T.M.; Björkman, M.P.; Kautiainen, H.; Strandberg, T.E.; Soini, H.; Suominen, M.H. Low protein and micronutrient intakes in heterogeneous older population samples. Arch. Gerontol. Geriatr. 2015, 61, 464-471. [CrossRef] [PubMed]

34. Best, R.L.; Appleton, K.M. The consumption of protein-rich foods in older adults: An exploratory focus group study. J. Nutr. Educ. Behav. 2013, 45, 751-755. [CrossRef] [PubMed]

35. Appleton, K.M. Barriers to and Facilitators of the Consumption of Animal-Based Protein-Rich Foods in Older Adults. Nutrients 2016, 8, 187. [CrossRef] [PubMed]

36. Herrema, A.L.; Westerman, M.J.; van Dingen, E.J.I.; Kudla, U.; Veltkamp, M. Combined protein-rich diet with resistance exercise intervention to counteract sarcopenia: A qualitative study of Drivers and Barriers of compliance. J. Aging Phys. Act. 2018, 26, 106-113. [CrossRef] [PubMed]

37. Ruxton, C.; Derbyshire, E.; Gibson, S. The nutritional properties and health benefits of eggs. Nutr. Food Sci. 2010, 40, 263-279. [CrossRef]

38. Smith, A.; Gray, J. Considering the benefits of egg consumption for older people at risk of sarcopenia. $\mathrm{Br}$. J. Community Nurs. 2016, 21, 305-309. [CrossRef] [PubMed]

39. Rousset, S.; Jolivet, P. Discrepancy between the expected and actual acceptability of meat products, eggs and fish: The case of older consumers. J. Sens. Stud. 2002, 17, 61-75. [CrossRef]

40. Drewnowski, A. The Nutrient Rich Foods Index helps to identify healthy, affordable foods. Am. J. Clin. Nutr. 2010, 91, 1095S-1101S. [CrossRef] [PubMed]

41. Lewis, B.R.; Bshin, A. Retailing policies for eggs: The implications of changes in consumer attitudes and behaviour. Br. Food J. 1988, 90, 172-177. [CrossRef]

42. Craig, P.; Dieppe, P.; Macintyre, S.; Michie, S.; Nazareth, I.; Petticrew, M. Medical Research Council Guidance. Developing and evaluating complex interventions: The new Medical Research Council guidance. BMJ 2008, 337, a1655. [CrossRef] [PubMed]

43. Michie, S.; van Stralen, M.M.; West, R. The behaviour change wheel: A new method for characterising and designing behaviour change interventions. Implement. Sci. 2011, 6, 42. [CrossRef] [PubMed] 
44. Van den Heuvel, E.; Murphy, J.L.; Appleton, K.M. Could Eggs Help Increase Dietary Protein Intake in Older Adults?-Exploring Reasons for the Consumption and Non-Consumption of Eggs in People over 55 years old. J. Nutri. Gerontol. Geriatr. 2018. [CrossRef]

45. Smith, W.; Mitcehll, P.; Reay, E.M.; Webb, K.; Harvey, P.W. Validity and reproducibility of a self-administered food frequency questionnaire in older people. Aust. N. Z. J. Public Health 1998, 22, 456-463. [CrossRef] [PubMed]

46. Tyrovolas, S.; Pounis, G.; Bountziouka, V.; Polychronopoulos, E.; Panagiotakos, D.B. Repeatability and validation of a short, semi-quantitative food frequency questionnaire designed for older adults living in Mediterranean areas: The MEDIS-FFQ. J. Nutr. Elder. 2010, 29, 311-324. [CrossRef] [PubMed]

47. Malmstrom, T.K.; Morley, J.E. SARC-F: A simple questionnaire to rapidly diagnose sarcopenia. J. Am. Med. Dir. Assoc. 2013, 14, 531-532. [CrossRef] [PubMed]

48. Millwood, J.; Heath, M.R. Food choice by older people: The use of semi-structured interviews with open and closed questions. Gerodontology 2000, 17, 25-32. [CrossRef] [PubMed]

49. Pliner, P.; Hobden, K. Development of a scale to measure the trait of food neophobia in humans. Appetite 1992, 19, 105-120. [CrossRef]

50. Marks, D.F.; Yardley, L. Research Methods for Clinical and Health Psychology; Sage Publications Inc.: London, UK, 2003.

51. Office for National Statistics. Census 2011. Available online: https://www.ons.gov.uk/census/2011census (accessed on 26 March 2018).

52. Green, S.B. How many subjects does it take to do a regression analysis. Multivariate Behav. Res. 1991, 26, 499-510. [CrossRef] [PubMed]

53. Field, A. Discovering Statistics using IBM SPSS Statistics; Sage Publications Inc.: London, UK, 2013.

54. Appleton, K.M.; McGill, R.; Neville, C.; Woodside, J.V. Barriers to increasing fruit and vegetable intakes in the older population of Northern Ireland: Low levels of liking and low awareness of current recommendations. Public Health Nutr. 2010, 13, 514-521. [CrossRef] [PubMed]

55. Locher, J.L.; Ritchie, C.S.; Roth, D.L.; Sen, B.; Vickers, K.S.; Vailas, L.I. Food choice among homebound older adults: Motivations and perceived barriers. J. Nutr. Health Aging 2009, 13, 659-664. [CrossRef] [PubMed]

56. Falk, L.W.; Bisogni, C.A.; Sobal, J. Food choice processes of older adults: A qualitative investigation. J. Nutr. Educ. 1996, 28, 257-265. [CrossRef]

57. Brondel, L.; Romer, M.; van Wymelbeke, V.; Pineau, N.; Jiang, T.; Hanus, C.; Rigaud, D. Variety enhances food intake in humans: Role of sensory-specific satiety. Physiol. Behav. 2009, 97, 44-51. [CrossRef] [PubMed]

58. Hollis, J.; Henry, C. Dietary variety and its effect on food intake of elderly adults. J. Hum. Nutr. Diet. 2007, 20, 345-351. [CrossRef] [PubMed]

59. Marshall, T.A.; Stimbo, P.J.; Warren, J.J.; Xie, X.J. Inadequate nutrient intakes are common and are associated with low diet variety in rural, community-dwelling elderly. J. Nutr. 2001, 131, 2192-2196. [CrossRef] [PubMed]

60. Rolls, B.J.; Rowe, E.A.; Rolls, E.T.; Kingston, B.; Megson, A.; Gunary, R. Variety in a meal enhances food intake in man. Physiol. Behav. 1981, 26, 215-221. [CrossRef]

61. Zandstra, E.; de Graaf, C.; Van Trijp, H. Effects of variety and repeated in-home consumption on product acceptance. Appetite 2000, 35, 113-119. [CrossRef] [PubMed]

62. Fearne, A.; Lavelle, D. Segmenting the UK egg market: Results of a survey of consumer attitudes and perceptions. Br. Food J. 1996, 98, 7-12. [CrossRef]

63. British Egg Industry Council. Egg Shaped History. Available online: http://www.gotoworkonanegg.co.uk/ egg_facts_figures.html (accessed on 26 March 2018).

64. Moss, C. Why Men Like Full English Breakfasts. Available online: https://www.telegraph.co.uk/men/ thinking-man/10680286/Why-men-like-full-English-breakfasts.html (accessed on 1 February 2016).

65. Delaney, M.; McCarthy, M. Food choice and health across the life course: A qualitative study examining food choice in older Irish adults. J. Food Prod. Market. 2011, 17, 114-140. [CrossRef]

66. Appleton, K.M. Increases in energy, protein and fat intake following the addition of sauce to an older person's meal. Appetite 2009, 52, 161-165. [CrossRef] [PubMed]

67. Appleton, K.M. Limited compensation at the following meal for protein and energy intake at a lunch meal in health free-living older adults. Clin. Nutr. 2018, 37, 970-977. [CrossRef] [PubMed] 
68. Best, R.L.; Appleton, K.M. Comparable increases in energy, protein and fat intakes following the addition of seasonings and sauces to an older person's meal. Appetite 2011, 56, 179-182. [CrossRef] [PubMed]

69. Mathey, M.F.; Siebelink, E.; de Graaf, C.; van Staveren, W.A. Flavor enhancement of food improves dietary intake and nutritional status of elderly nursing home residents. J. Gerontol. A Biol. Sci. Med. Sci. 2001, 56, M200-M205. [CrossRef] [PubMed]

70. Chambers, L.; Ells, H.; Yeomans, M.R. Can the satiating power of a high energy beverage by improved by manipulating sensory characteristics and label information? Food Qual. Pref. 2013, 28, 271-278. [CrossRef]

71. Cioffi, C.E.; Levitsky, D.A.; Pacanowski, C.R.; Bertz, F. A nudge in a healthy direction. The effect of nutrition labels on food purchasing behaviors in university dining facilities. Appetite 2015, 92, 7-14. [CrossRef] [PubMed]

72. Yeomans, M.R.; Re, R.; Wickham, M.; Lundholm, H.; Chambers, L. Beyond expectations: The physiological basis of sensory enhancement of satiety. Int. J. Obes. (Lond.) 2016, 40, 1693-1698. [CrossRef] [PubMed]

73. Herman, C.P.; Roth, D.A.; Polivy, J. Effects of the presence of others on food intake: A normative interpretation. Psychol. Bull. 2003, 129, 873-886. [CrossRef] [PubMed]

74. Robinson, E.; Fleming, A.; Higgs, S. Prompting healthier eating: Testing the use of health and social norm based messages. Health Psychol. 2014, 33, 1057-1064. [CrossRef] [PubMed]

75. Johnston, L.C.; Macrae, C.N. Changing social stereotypes: The case of the information seeker. Eur. J. Soc. Psychol. 1994, 24, 581-592. [CrossRef]

76. Van der Zanden, L.D.T.; van Kleef, E.; de Wijk, R.A.; van Trijp, H.C.M. Examining heterogeneity in elderly consumers' acceptance of carriers for protein-enriched food: A segmentation study. Food Qual. Pref. 2015, 42, 130-138. [CrossRef]

77. Van der Zanden, L.D.T.; van Kleef, E.; de Wijk, R.A.; van Trijp, H.C.M. Knowledge, perceptions and preferences of elderly regarding protein-enriched functional food. Appetite 2014, 80, 16-22. [CrossRef] [PubMed]

78. Sidenvall, B.; Nydahl, M.; Fjellström, C. Managing food shopping and cooking: The experiences of older Swedish women. Ageing Soc. 2001, 21, 151-168. [CrossRef]

79. Barraj, L.; Tran, N.; Mink, P. A comparsion of egg consumption with other modifiable coronary heart disease lifestyle risk factors: A relative risk apportionment study. Risk Anal. 2009, 29, 401-415. [CrossRef] [PubMed]

80. Griffin, B.A. Eggs: Good or bad? Proc. Nutr. Soc. 2016, 75, 259-264. [CrossRef] [PubMed]

81. Scafford, C.G.; Tran, N.L.; Barraj, L.M.; Mink, P.J. Egg consumption and CHD and stroke mortality: A prospective study of US adults. Public Health Nutr. 2011, 14, 261-270. [CrossRef] [PubMed]

82. McKie, L.; MacInnes, A.; Hendry, J.; Donald, S.; Peace, H. The food consumption patterns and perceptions of dietary advice of older people. J. Hum. Nutr. Diet. 2000, 13, 173-183. [CrossRef] [PubMed]

83. Djoussé, L.; Gaziano, J.M.; Buring, J.E.; Lee, I.M. Egg consumption and risk of type 2 diabetes in men and women. Diabetes Care 2009, 32, 295-300. [CrossRef] [PubMed]

84. Hu, F.B.; Stampfer, M.J.; Rimm, E.B.; Manson, J.E.; Ascherio, A.; Colditz, G.A.; Rosner, B.A.; Spiegelman, D.; Speizer, F.E.; Sacks, F.M.; et al. A prospective study of egg consumption and risk of cardiovascular disease in men and women. JAMA 1999, 281, 1387-1394. [CrossRef] [PubMed]

85. Weightwatchers. Available online: https://www.weightwatchers.com/us/ (accessed on 26 March 2018).

86. Appleton, K.M.; Woodside, J.V.; Yarnell, J.W.G.; Arveiler, D.; Haas, B.; Amouyel, P.; Montaye, M.; Ferrieres, J.; Ruidavets, J.B.; Ducimetiere, P.; et al. Depressed mood and dietary fish intake: Direct relationship or indirect relationship as a result of diet and lifestyle? J. Affect. Disord. 2007, 104, 217-223. [CrossRef] [PubMed]

87. Molag, M.L.; de Vries, J.H.; Ocké, M.C.; Dagnelie, P.C.; van den Brandt, P.A.; Jansen, M.C.J.F.; van Staveren, W.A.; van't Veer, P. Design characteristics of food frequency questionnaires in relation to their validity. Am. J. Epidemiol. 2007, 166, 1468-1478. [CrossRef] [PubMed]

88. Tjonneland, A.; Haraldsdottir, J.; Overvad, K.; Stripp, C.; Ewertz, M.; Jensen, O.M. Influence of individually estimated portion size data on the validity of a semi-quantitative food frequency questionnaire. Int. J. Epidemiol. 1992, 21, 770-777. [CrossRef] [PubMed]

(C) 2018 by the authors. Licensee MDPI, Basel, Switzerland. This article is an open access article distributed under the terms and conditions of the Creative Commons Attribution (CC BY) license (http:/ / creativecommons.org/licenses/by/4.0/). 